\title{
INVESTIGATION OF HUMUS AND NITRATE CONTENT OF SOIL WITH SPECIAL REFERENCE TO THE NITRATE SENSITIVITY
}

\author{
Judit Petö ${ }^{{ }^{*}}$, Attila Hüvely ${ }^{1}$, Imre Cserni ${ }^{2}$ \\ ${ }^{1}$ Department of Agricultural Science, Faculty of Horticulture and Rural Development, John von Neumann \\ University, Kecskemét, Hungary \\ ${ }^{2}$ professor emeritus of the Faculty of Horticulture and Rural Development, John von Neumann University, \\ Kecskemét, Hungary \\ https://doi.org/10.47833/2020.2.AGR.013
}

\begin{tabular}{|c|c|}
\hline $\begin{array}{l}\text { Keywor } \\
\text { Soil nitrat } \\
\text { Organic n } \\
\text { Correlatio } \\
\text { Nitrate se } \\
\text { Good agr }\end{array}$ & $\begin{array}{l}\text { S: } \\
\text { content } \\
\text { terial } \\
\text { studies } \\
\text { sitive area } \\
\text { ultural pract }\end{array}$ \\
\hline Article & story \\
\hline Received & 28 Jan 2020 \\
\hline Accepted & 25 Feb 20 \\
\hline
\end{tabular}

\section{Introduction}

The easy-to-absorb forms of nitrogen in the soil solution for cultivated plants are mainly the ammonium and nitrate ions. However, less than $0.1 \%$ of the total nitrogen stock fraction is readily absorbed in the soil, on average. The vast majority of nitrogen is found bound in various organic compounds, humus substances, microorganisms and dead biomass remains. Thus, the breakdown of soil organic matter determines the natural $\mathrm{N}$-supply capacity of the soil [3].

The nitrate content of the soil is also affected by the mineralization of the organic matter content and the amount and form of the fertilizer or organic fertilizer used. Therefore, its level may change significantly over time. Furthermore, uptake by the plants - this is the goal really - and the loss of soil due to leaching may be significant. Due to the negative charge of the surface of the soil colloids, the anion exchange capacity is relatively small. Thus, irrigation, weather, rainfall and possible water cover are also very important influencing factors [1].

Under aerobic conditions, the nitrate content of the soil shows the mineral nitrogen content that can be directly absorbed by the plants [3].

Under anaerobic conditions, the activity of denitrifying bacteria / microorganisms reduces the leaching of nitrate to a certain extent, and thus may delay environmental eutrophication processes. Nitrogen is one of the most important macronutrients in plant life, but too much nitrate can have harmful effects on soil, the environment and thus human health as well. The high nitrate content of

\footnotetext{
* Corresponding author. Tel.: +36 76517661

E-mail address: peto.judit@kvk.uni-neumann.hu
} 
waters and foods may cause problems in many parts of the EU, so the Nitrate Directive regulates the necessary preventive measures and limit values which must be kept to avoid the risk of nitrate pollution [17].

EU agricultural support has provided significant resources for the establishment and modernization of vineyards and fruit orchards over several cycles. However, a significant part of the country is classified as a nitrate-sensitive area and therefore the application of nitrogen is restricted in these areas.

From 2006, 46\% of Hungary's territory, and from 1 September 2013, approximately $70 \%$, was classified as nitrate-sensitive. The rules of good agricultural practice should be kept in these areas from 2007 (green color) or 2014 (red color), as shown in Figure 1.

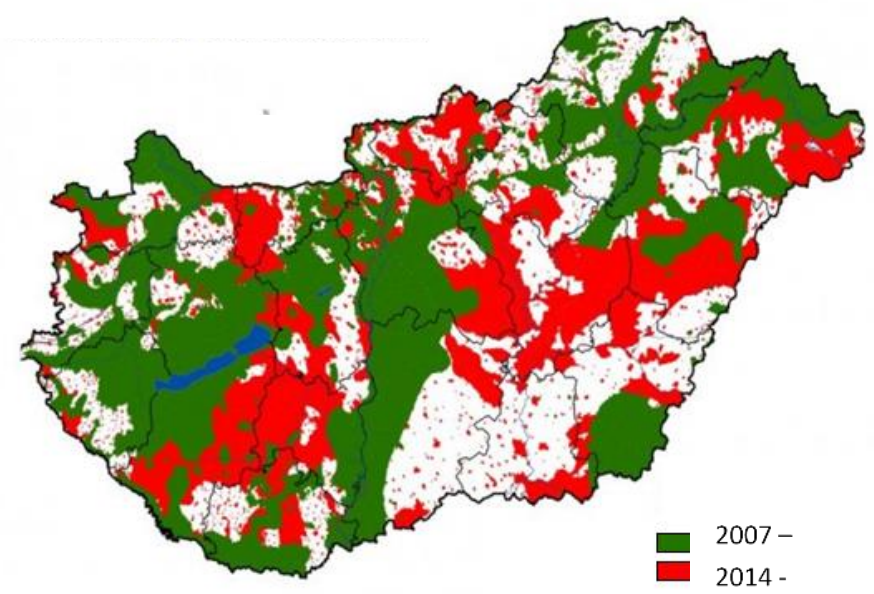

Figure 1. Nitrate-sensitive areas in Hungary, signed with green and red colors (Ministry of Rural Development, State Secretariat for Agriculture, 2013 [16])

As a result, many farmers are affected by the requirements of the Directive $[15,16]$. Compliance with the directive limits, nutrient delivery in both time and quantity would be controlled. Specifications include that fertilizer use in nitrate sensitive areas is allowed only if it was based on soil tests not older than 5 years. In soil tests of nitrate sensitive areas, besides the determination of the most important soil physical properties ( $\mathrm{pH}$, soil plasticity, salt, lime and humus content), the measurement of the three most important, major plant nutrients $(N, P, K)$ is required, in the frame of so called "restricted soil test pack".

The organic matter content of soil is a complex mixture of organic compounds, including humic acid, fulvic acid, humic substances, proteins and polysaccharides and their metabolites. Organic colloids have large specific surfaces and ion exchange capacity, so significantly affect the fertility and nutrient supply of soils in general $[5,6]$.

The laboratory of the Faculty of Horticulture and Rural Development connected to thousands of farmers, testing continuously physical and chemical analysis of the soil samples. In our study we were on following nitrate content of soil with special reference to the nitrate sensitivity. We followed correlation between organic matter and nitrate content as well.

\section{Materials and methods}

Soil samples, received among 2015-2017 years, were processed in the Accredited Soil and Plant Testing Laboratory at the Faculty of Horticulture and Rural Development, John von Neumann University. The number of samples processed was highly significant: it was 5640 in 2015, 5160 in 2016 and 8730 samples in 2017. Most of the soil samples derived from the southern part of the Great 
Plain, mainly from vineyards and orchards, and in a small extent (about 15\%) from fields. The depth of sampling was $0-30 \mathrm{~cm}$, and $30-60 \mathrm{~cm}$ as well in the case of plantations.

Soil tests were made by standard methods. Organic matter content was determined photometrically after dichromate / sulfuric acid digestion, and was expressed in $\mathrm{m} / \mathrm{m} \%$ airdry matter. Determination range was from 0.2 to $4.0 \mathrm{~m} / \mathrm{m} \%$ humus content. Nutrient contents were determined from soil extracts prepared according to standard $1 \mathrm{~mol} / \mathrm{dm}^{3} \mathrm{KCl}$ extraction method. $\left(\mathrm{NO}_{2}{ }^{-}+\mathrm{NO}_{3}{ }^{-}\right)-\mathrm{N}$ measurements were performed using FIA Star spectrophotometry. As $\mathrm{NO}_{2}{ }^{-}$level in the soil is very low - compared to the $\mathrm{NO}_{3}{ }^{-}$level in the soil, under normal circumstances -, results were expressed in $\mathrm{NO}_{3}-\mathrm{N} \mathrm{mg} / \mathrm{kg}$ airdry matter. Distribution of $\mathrm{NO}_{3}-\mathrm{N}$ levels in three consecutive years was also estimated. The frequency of date (\%) in different ranges was calculated.

Pearson's linear correlation analysis was performed to reveal the relationships between the examined parameters, and the significant relationships were determined at significance levels of $5 \%$, $2 \%, 1 \%$ and $0.1 \%$.

\section{Results}

Most of the samples, arrived into our laboratory in this period, derived from the Southern Great Plain region of the country. Our data show, that there was a very strong correlation between organic matter content and NO3-N level of the soil (Table 1). Correlation was the strongest in 2017, the number of samples was the highest in this year as well. Organic matter contents (expressed in $\mathrm{H} \%$ ) ranged from the minimum of lower than $0.20 \mathrm{~m} / \mathrm{m} \%$ to the maximum of $4.53 \mathrm{~m} / \mathrm{m} \%$. Humus content in the samples were generally in the lower concentration range.

Table 1. Correlation between soil organic matter and $\mathrm{NO}_{3}-\mathrm{N}$ level (2015-2017)

\begin{tabular}{|c|c|c|c|}
\hline \multirow{2}{*}{ Year } & $\begin{array}{c}\text { No. of } \\
\text { samples }\end{array}$ & $\begin{array}{c}\text { Correlation } \\
\text { coefficient }\end{array}$ & $\begin{array}{c}\text { Significance } \\
\text { level }\end{array}$ \\
\cline { 2 - 4 } & $\mathbf{n}$ & $\mathbf{r}\left(\mathrm{H}^{2}-\mathrm{NO}_{3}-\mathrm{N}\right)$ & $\mathbf{p}$ \\
\hline 2015 & 5640 & 0.2756 & $<0.001$ \\
\hline 2016 & 5160 & 0.3144 & $<0.001$ \\
\hline 2017 & 8730 & 0.4133 & $<0.001$ \\
\hline
\end{tabular}

Average nitrate levels were in the $10-25 \mathrm{mg} / \mathrm{kg}$ range, the average was the highest in 2015 , and the lowest in 2016 (Table 2).

$\mathrm{NO}_{3}-\mathrm{N}$ level spread on a large scale, showed large distribution, from a minimum of $<1.00$ $\mathrm{mg} / \mathrm{kg}$, up to $400 \mathrm{mg} / \mathrm{kg}$ (Fig. 2).

Table 2. Average nitrate levels in the soil samples in 2015-2017 period

\begin{tabular}{|r|r|}
\hline \multirow{2}{*}{ Year } & \multicolumn{1}{|c|}{$\mathrm{NO}_{3}-\mathrm{N}$} \\
\cline { 2 - 2 } & $\mathrm{mg} / \mathrm{kg}$ \\
\hline 2015 & 24.2 \\
\hline 2016 & 12.1 \\
\hline 2017 & 18.4 \\
\hline
\end{tabular}




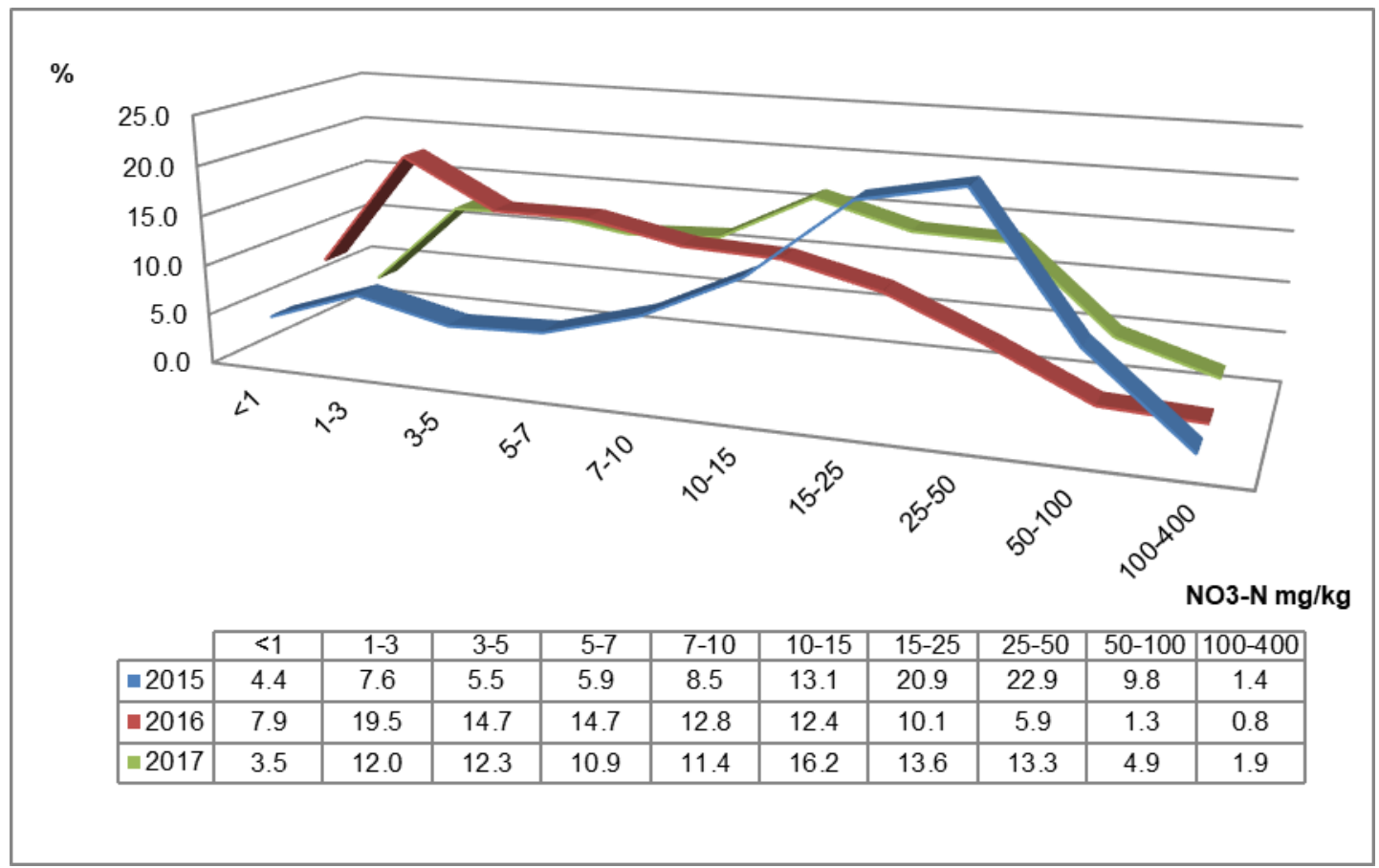

Figure 2. Distribution of nitrate levels in the samples in 2015, 2016 and 2017

\section{Discussion}

The nitrogen content of the soil organic compounds is relatively constant, so the distribution of nitrogen in the soil profile is the same as that of the organic matter [3]. Degradation of organic matter in soil results nutrient source for cultivated plants, so - for estimating nitrogen demand -, soil experts make the nutrient supply plan to the farmers on the base of organic matter level.

In practice, farmers carry out soil sampling in five-year intervals at plantations and fields. Good agricultural practice, under regulation, calls for sampling after harvest and before fertilization. Sampling is recommended at least 100 days after autumn fertilization. A waiting period of 100 days after fertilization and six months after organic fertilization is recommended [15].

In nitrate-sensitive areas, manure application is prohibited during a defined winter period, the amount of organic fertilizer that can be applied is limited, and farmers have to take into account the slope of the area and, of course, the nutrient requirements of the crop in phenophase-dependent manner. When determining the amount of nutrient to be applied by fertilization, the site conditions, the nutrient supply of the soil and the nutrient requirement of the crop to be cultivated should also be taken into account.

Our study areas were not characterized by inland water, they were well-ventilated, and in a large extent, sandy textured soils. Thus, of the inorganic nitrogen forms, the amounts of ammonium and nitrite are negligible, the main form of nitrogen is nitrate-nitrogen [4].

We showed that nitrate level was highly associated with soil organic matter content. Nitrate concentrations showed large variation either, reaching about $400 \mathrm{mg} / \mathrm{kg}$ level in some cases. In about $1.5 \%$ of the samples nitrate-nitrogen concentration reached the $100 \mathrm{mg} / \mathrm{kg}$ level.

From an environmental point of view, it would be important to determine the nitrate content of the soil in late winter or early spring. This sampling indicates the initial amount of mineral nitrogen for the vegetation period. In early spring, the soil temperature is still low, so microbiological activity has not started [8,9]. At this point, the humus is not mineralized yet [14]. This sampling method can be used to determine the early spring nitrogen content of the soil, which can be taken up by plants easily and needs to be taken into account in nutrient calculations [13]. It is recommended that early spring sampling and nitrate determination should be more widespread in practice as it may provide more accurate value than the calculation of nitrogen dose only from the humus content. 
In many cases, sampling and laboratory testing is carried out after the harvest. This nitrate level cannot be used for calculation of the nitrogen fertilization in the following season, as its value may decrease significantly until spring, due to leaching losses [2]. However, it is important from an environmental point of view: when a farmer applies too much nitrogen or inadequately distributed active ingredient during the growing season, or there is little rainfall or irrigation, the plant is unable to uptake all the nitrogen and it would be largely wasted during winter. If the measured value exceeds the value of about $5-10 \mathrm{mg} / \mathrm{kg}$ nitrate-nitrogen, too much nitrogen was released during the growing season, the plant could not absorb it and the nitrate contamination in the environment could be expected. This can be justified by determining the nitrate leaching into the deeper soil layers (it is advisable to follow the nitrogen profile in the deeper layers of the soil), or even its appearance in the groundwater or - in the case of erosion - losses in the surrounding areas.

Our soil samples were taken mainly either in the early spring or in the late summer-autumn part of the year. Two-thirds of the samples in 2015, one-third of the samples in 2016 and $50 \%$ of the samples in 2017 showed nitrate-nitrogen values higher than $10 \mathrm{mg} / \mathrm{kg}$ (this is also about the limit allowed for drinking water).

Our former studies showed that organic matter contents in the samples were generally low and showed significant variation [11,12]. Organic fertilization and manure use are highly recommended to improve soil structure and nutrient holding and storage capacity in soils $[5,6,7,10]$. Controlled use of organic matters in plant growing may have beneficial effects in reducing nitrate leaching in the nitrate sensitive areas of our region.

Our results - based on testing more than ten thousand samples - show that nitrate- $\mathrm{N}$ content of the soil was in a very close positive correlation with the organic matter content of the soil $(p$ $<0.001$ ).

In our further studies we are on following the seasonal variation of nitrate levels and estimating the cultivation dependent soil concentrations and use of nitrogen fertilizers.

\section{Conclusion}

The relationship between organic matter and soil nitrate level was very strong.

We found nitrate-nitrogen levels higher than $100 \mathrm{mg} / \mathrm{kg}$ in about $1.5 \%$ of the tested soils, which were characterized with generally low humus content. In our samples values higher than $10 \mathrm{mg} / \mathrm{kg}$ were significant. The high nitrate content makes it probable that the required waiting time after fertilization was not held at the sampling or that excess nitrate remained in the soil at the end of the growing season.

Water soluble nitrate, remaining in the soil at the end of the growing season, is not relevant for nutrient supply and digestion for the following year, since much of it is removed from the root zone during winter and in this way, can cause environmental damage.

Increasing or re-supplementation of the organic matter content is also important for reducing nitrate leaching. Controlled use of organic fertilization and/or recycling of the organic matter is extremely important in sandy soils to balance nitrate and other nutrient levels in the soil.

\section{Acknowledgment}

Authors wish to thank for the support of EFOP-3.6.2-16-2017-00012 „Development of a product chain model for functional, healthy and safe foods from farm to fork based on a thematic research network" project. This project is supported by the Hungarian State and the European Union, co-financed by the European Social Fund, under the Széchenyi 2020 program. 


\section{References}

[1] Berenguer P, Santiveri F, Boixadera J, Lloveras J. (2008) Fertilization of irrigated maize with pig slurry combined with mineral nitrogen. Eur J Agron. 28. pp. 635-45. doi:10.1016/j.eja.2008.01.010

[2] Booltink, H. W. G. (1995). Field monitoring of nitrate leaching and water flow in a structured clay soil. Agriculture, ecosystems \& environment, 52(2-3), pp. 251-261

[3] Füleky Gy., Sárdi K. (2014): Tápanyag-gazdálkodás, Mezőgazda Kiadó, Budapest, 259. p.

[4] Filep Gy., Füleky Gy., Stefanovits P. (2010): Talajtan, Mezőgazda Kiadó, Budapest, 470. p.

[5] Jiménez Becker S, Ebrahimzadeh A., Plaza Herrada BM, Lao M.T. (2010): Characterization of compost based on crop residues: changes in some chemical and physical properties of the soil after applying the compost as organic amendment. Commun. Soil Sci. Plant Anal. 41. pp. 696-708. doi:10.1080/00103620903563931

[6] Johnston, A. E. (1986). Soil organic matter, effects on soils and crops. Soil use and management, 2(3), pp. 97105.

[7] Kádár, I. (2015): Összefüggések a talaj termékenysége és tápanyagellátottsága között. MTA Talajtani és Agrokémiai Kutatóintézet (MTA ATK TAKI), 389. p.

[8] Koranda, M., Kaiser, C., Fuchslueger, L., Kitzler, B., Sessitsch, A., Zechmeister-Boltenstern, S., Richter, A. (2013) Seasonal variation in functional properties of microbial communities in beech forest soil. Soil Biology and Biochemistry, 60, pp. 95-104. DOI: 10.1016/j.soilbio.2013.01.025 /

[9] Moore-Kucera, J., Dick, R. P. (2008) PLFA profiling of microbial community structure and seasonal shifts in soils of a Douglas-fir chronosequence. Microbial ecology, 55(3), pp. 500-511. https://doi.org/10.1007/s00248-0079295-1

[10] Mugnai S, Mais E, Azzarello E, Mancuso S. (2012) Influence of long-term application of green waste compost on soil characteristics and growth, yield and quality of grape (Vitis vinifera L.). Compost Sci Utiliz. 20: pp. 29-33. doi:10.1080/1065657X.2012.10737019

[11] Petö J., Hüvely A., Vojnich V. J., Cserni I. (2019) A talaj felvehető tápelemeinek összefüggése a vízoldható sótartalommal. Gradus, 6. 2, pp. 33-38.

[12] Pető J., Hüvely A., Vojnich V. J., Cserni I. (2020): Investigation of the relationship between soil organic matter and magnesium content Gradus 7. 1. pp. 53-56.

[13] Smith R. (2013): High residual soil nitrate levels this spring, Salinas Valley Agriculture https://ucanr.edu/blogs/blogcore/postdetail.cfm?postnum=7102 [Accessed: 19-Jan-2020]

[14] Štursová, M., Baldrian, P. (2011) Effects of soil properties and management on the activity of soil organic matter transforming enzymes and the quantification of soil-bound and free activity. Plant and soil, 338(1-2), pp. 99-110. doi https://doi.org/10.1007/s11104-010-0296-3

[15] 27/2006. (II. 7.) Korm. rendelet A vizek mezőgazdasági eredetű nitrátszennyezéssel szembeni védelméről.

[16] 43/2007. (VI. 1.) FVM rendelet A nitrátérzékeny területeknek a MePAR szerinti blokkok szintjén történő közzétételéröl.

[17] 59/2008. (IV. 29.) FVM rendelet A vizek mezőgazdasági eredetű nitrátszennyezéssel szembeni védelméhez szükséges cselekvési program részletes szabályairól, valamint az adatszolgáltatás és nyilvántartás rendjéről. 